\title{
DIGITALCOMMONS
}

@WAYNESTATE-

Criticism

Volume 52

Issue 2 Honoring Eve: A Special Issue on the

Work of Eve Kosofsky Sedgwick

2010

\section{Unreason, Love, and Un-Becoming Queer}

renée c. hoogland

Wayne State University, reneehoogland@wayne.edu

Follow this and additional works at: https://digitalcommons.wayne.edu/criticism

\section{Recommended Citation}

hoogland, renée c. (2010) "Unreason, Love, and Un-Becoming Queer," Criticism: Vol. 52: Iss. 2, Article 17.

Available at: https://digitalcommons.wayne.edu/criticism/vol52/iss2/17 
UNREASON, LOVE, AND UN-BECOMING QUEER

renée c. hoogland

\section{Mad for Foucault: Rethinking the} Foundations of Queer Theory by Lynne Huffer. Gender and Culture series. New York City: Columbia University Press, 2009. Pp. 376, 10 illustrations. $\$ 84.50$ cloth, $\$ 27.50$ paper.
Mad for Foucault, Lynne Huffer's recent attempt at "rethinking the foundations of queer theory" - as the book's subtitle runs-is, in a way, a rather maddening read. Whether this is because Huffer is, by her own admission, madly in love with (her) "Foucault," or because her main subject is Foucault's first major work, The History of Madness, published in French in 1961, but only fully translated into English and published by Routledge in 2006, I am not so sure. Madness, as Foucault's famous argument suggests, cannot speak itself; the madman is relegated to silence or to the outside of civilization, and his (non)existence can only be spoken by the voice of morality, reason, and/or (medical) science. Any discourse about madness, however humble or selfeffacing, thus cannot but ultimately repeat some of the gestures of precisely the positivist production of the negativity of madness that it is Foucault's, and in his wake, Huffer's project to lay bare, and subvert. Hence, I find myself dancing around discursive impossibilities, if not aporias, that inhere in Foucault's original Madness, as much as in the "ironic terms" of Huffer's productive encounter with this book as "object-event" (x), a happening, or "coup de foudre" (10), which, while starting off with Foucault's question "why [have] we made sexuality into a moral experience?" (xv), gradually 
becomes "[her] own story of love" (16).

As a story of love, Huffer's book is as much a loving embrace of a newly discovered, or, better, a discursively recovered, "Foucault," as it is an embrace of the archive, a succumbing to the "archive fever" that she had never experienced before she spent a month in the Foucault archives in Normandy in 2006, shortly after the "translationevent," the appearance in English of The History of Madness (hereafter, Madness). The (to an Englishspeaking audience) more familiar title Madness and Civilization: A History of Insanity in the Age of Reason (1965) is a translation of the truncated French version, an inexpensive paperback edition of 230 pages (about one-third the length of the original), which came out soon after the original, and which, to Foucault's apparent chagrin, became the standard edition of the book. To complicate this erratic publishing history even further: a revised edition of the 1961 original appeared in French 1972, with a new preface by Foucault - a "marvelous, self-ironizing" one, in Huffer's words, that stands in stark contrast to, and thus forms a "distorting mirror" to the "overly poetic, 'lyrical' voice of the young Foucault" (x) that speaks the (subsequently suppressed) 1961 preface. Huffer foregrounds the "distorting mirror" of the Foucauldian archive, its doublevoicedness-Foucault, as Deleuze reminds us, "is haunted by the double and its essential otherness" (xii) - to build on the rupturing event of Madness, and embraces its disruptive publication history to testify to its "importance for our present post-queer age" (x). Reading Madness retrospectively, which, in the context of queer theory, and its almost exclusive focus on Foucault's History of Sexuality One, is also to read it prospectively, her aim is, appropriately, dual: on the one hand, she wants to stipulate the material presence of the archive, in casu, to mark the traces or ghosts of the historically variably defined "madmen"_-including, but not restricted to, the figures of sexual unreason, or queers - and, on the other, to "unravel some of the blind spots" (xi) of queer theory and offer a reading of Madness that will allow for a "political ethos of eros" as a practice of self-transformation as a "possibility of alteration in our historical present" (261).

Huffer goes about her ambitious undertaking in five, relatively long chapters, preceded by-perversely - a preface, as well as an introduction, interspersed with four "interludes," and concluding with a "postlude." Each of the chapters takes on the larger challenge of relaunching a radical form of queer theory in this, our "present post-queer age," by a thorough exploration of one or more aspects of Madness, Foucault's monumental, and arguably founding, narrative on sexuality and ethics, the 
urtext, so to speak, that puts both Sexuality One (1978) and the last two volumes of The History of Sexuality_The Use of Pleasure (1984) and The Care of the Self (1984) into a significantly different light. The interludes serve to offer us insight into the personal and professional contexts that render/ed Huffer's passionate encounter with "Foucault" such a deeply unsettling, yet enabling one; to clarify her urge to dislodge traditional thinking about one of the principal figures in sexuality studies, by, inter alia, un-coupling the "FreudoFoucauldian foundations" (164) of queer theory; and to undo the "performative logic" of (some of) its most prominent practitioners.

Huffer's need, in the introduction, to give an "account of herself"- - to obliquely recall the title of a book by one of her main critical targets, Judith Butler-and to explain her desire to engage with Foucault as a queer feminist, and as professor and chair of Women's Studies at Emory University at that, is not altogether surprising in view of Foucault's track record as a gender-blind thinker. Her feminist "defense" nonetheless struck me as somewhat laborious, and, in its exhaustiveness, unnecessary. Her thorough critique of philosophical dismissals of Madness (most famously, by Jacques Derrida), in contrast - a thoroughness that is sustained throughout the subsequent chapters-almost immediately persuaded me of the va- lidity of Huffer's chosen task (i.e., to "re-queer Foucault"), as well as of the political significance of her overall philosophical argument.

Huffer (re)reads Foucault's genealogy of the "structure of the experience of madness," which he himself admits is a "doubly impossible task" (28) (since madness cannot be captured nor can its truth be spoken), through the lens provided by Gilles Deleuze in Foucault (1986), published two years after Foucault's death. While Foucault himself insisted on his role as a nonhistorian and a nonphilosopher, Deleuze foregrounds the complex relation between these two fields in Foucault's concept of subjectivity as subjectivation, a conception Huffer, in her turn, calls "coextensive" (29). Drawing on the Deleuzian concept of the fold, she elaborates a notion of coextension that at once covers the "cartography that encompasses the complex relations among social, historical, political, linguistic, and conceptual fields," and that renders the subject "coterminous, contingent, or contiguous with an outside that is in a continual process of transformation and expansion" (31). It is this idea of subjectivation as an ongoing process of becoming (other), as coterminous rather than produced-or constructed-in interaction with its "constitutive outside" that will lead Huffer through Madness, and that ultimately opens the way to the proposed "political ethic of 
eros." Before she, and thus we, her (and Foucault's) readers, reach this point, however, a moment of opening up to a future, she/we have a long and occasionally tortuous way to go through what at moments feels like a labyrinthine trek through a both unfolding and enfolding discursive archive.

The historical journey of the subject truly begins with the production of madness (and, importantly, of nonnormative sexualities) at the "moment of division between reason and its others" (40), the "Cartesian coup of the cogito" (74) that produced subjectivity through "structures of moral exclusion" (40). The next stage takes us, under Huffer's erudite guidance, through Nietzsche's critique of morality, and especially his "evocation of Dionysian intoxication and nonrationality as a creative force" (87)—so palpably present in Foucault's thoughtbut also to the image of Nietzsche's undoing, his fall into madness, which, rather than a romantic celebration of transgressive insanity, as some of Foucault's critics would have it, serves to expose the "price exacted by rationalist moralism from those who resist its despotic order" (88). Huffer's engagement with Nietzsche's "moral subject," with the production of "bad conscience" through the "unfolding of the interiority of a seemingly selfcontained subject with an 'inside,' a 'psyche,' or a 'soul'” (91), allows her both to connect the production of sexuality as an "inner" essence to the structures of rational morality of the classical age and further to evolve her critique of the FreudoFoucauldian link in queer theory and, therewith, of the model of sexuality in terms of performativity.

As earlier suggested, Judith Butler is singled out as the primary target of Huffer's postqueer critique, being the "most famous, indeed founding example of [queer theory's] performative logic" (113). Elsewhere, she more approvingly refers to Eve Sedgwick (praised for asking "paradigmatically" Foucauldian questions [92]), while she altogether dismisses, on both political and theoretical grounds, Leo Bersani's and Lee Edelman's "psyche-driven 'anti-social' thesis" for continuing to "assume the existence of a psyche as a container of the subject's death" (115). Her critique of Butler's performative model is, in my view, both sound and convincing, and constitutes one of the (many) enabling moments for my own thinking about being/becoming, and not only in terms of gender/sexuality.

Huffer readily admits that Butler's reversal of the sex/gender distinction, so that the primacy of sex (nature) over gender (culture) is dismantled, is "no small feat" (113). She goes on to point out, however, that performativity's dialectical logic not only reinforces the binary opposition between acts and identities most queer readers of Fou- 
cault have wrongly considered to form the center of his argument in Sexuality One, but also "deploys an apparatus of cause-effect reversal and sublation" (113) that differs from Foucault's much more radical attempt to "do away with the subject altogether." The subversive or parodic "resignification" of normative gender/sexual identities leaves the lethal power of Cartesian rationalism, bourgeois moralism, and Freudian psychoanalysis intact, in that it does nothing to undo the production of interiority, the internalization of morality (or, alternatively, of pathology) that condemns the (post)Enlightenment subject to its "caged freedom"; in other words, by failing to address the "historical problem of the normative internalization of violence" (116), queer performativity leaves intact that which Nietzsche, and Foucault with him, considered the "'serious illness' that is the psyche or the soul" (114). Foucauldian "desubjectivation," in contrast, takes Nietzsche's critique of moral interiority ultimately to a renegotiation of subjectivity itself, promising, in Huffer's terms, "forms of self-transformation we might imagine not as expansions of the self but as self-unravelings."

To be sure, Huffer is fully aware that "desubjectivation as becoming-other" means losing oneself completely or, indeed, to "be stark raving mad" (123). But despite the fact that this is a "horrifying proposition" (123), especially to those of us who have witnessed or experienced such madness up close, and that it is, in fact, impossible to really know what "desubjectivation as becoming-other" means, she wants to maintain the possibility of at least trying to think, or dream, the self otherwise; that is, beyond the constituting violence of the cogito and the equally violent "Freudian coup that establishes paternal authority within the sovereign structure of the Oedipus complex" (153). To this end, she extensively explores the function of Denis Diderot's Rameau's Nephew, first published in 1805 in German translation by Goethe, as, Huffer submits, a central text for a nineteenth-century Hegel and the French Hegelians of the twentieth century. Presented as a threshold figure of modernity, Rameau's nephew, "Diderot's split subject," is as required a character for Foucault as he is for Huffer, in that he embodies a limit experience, a figure whose "aporetic irony" undermines the "epistemological, ethical, and aesthetic rationalizations of the enlightened subject" (200). As a figure of modern madness, the self-mocking nephew inhabits a heterotopian space at the heart of Foucault's Madness (nine pages smack in the middle of the book, apparently, center on this "queer nephew") and opens up, in Huffer's project, the "possibility of... queering reason's heteronormative filiations." And this is, as suggested before, the core of Huffer's attempt 
at rereading Foucault as an ethical project, that is, to think (or dream) ethics as a question of subjectivity, which, it will be clear, entails, as much as it requires, the undoing of the moral subject of reason per se.

Ironically, when Huffer finally fully unfolds her model of a "political ethic of eros," she moves away from the discourse of Madness and retroactively reads its narrative of desubjectivation as a prelude to Foucault's (controversial) later writings on ethics in the ancient world, his defense of the care of the self, of an ethics of eros as a transformative rethinking of life. Foucault's arts of existence, she maintains, should be viewed as a "practice of philosophy and history [that] insists on the importance of the other" (275), as explicitly concerned with alterity, an often-overlooked aspect of his lifelong work, which nonetheless prominently emerges from his careful attention to the traces of those discarded lives, the ghosts of history illuminated in/by his archival work. Antiromantic and antiirrational, Foucault's ethics of eros is thus offered as the "intense thinking-feeling - an erotic curiosity as care- - toward the wounded vulnerability of the beloved other" (277-78).

Attractive, compelling, and, indeed, indisputably much more enriching and enabling than either anti-utopian queer discourses à la Bersani and Edelman, or David Halperin's reduction of a transfor- mative practical ethics to queer sexual practices such as gay fisting, or, indeed, the parodic resignification of normative gender and sexual identities through performative subversion, I, paradoxically, find myself somewhat disappointed with this tender ending of Huffer's passionate, occasionally dazzling love story. This is, I guess, the operation of what Linda Hutcheon calls “irony's edge" - approvingly cited by Huffer in her chapter on Diderot's Nephew. For when I described my reading experience of this book, in my opening paragraph, as "maddening," I was not quite aware yet of either the implications of or the reasons for this readerly effect. Having retraversed Huffer's argument in the process of writing this review, however, I think my sense of un-ease springs from the affective dissonance generated by the "unsettling duplicity" of a discourse that effectively invites us to partake in an unraveling of all our ideas about ourselves, about sexuality, about subjectivity, about subjectivation as such. I am infinitely more attracted by the centrifugal force of madness as desubjectivation, as un-becoming, however "horrifying" a proposition it may be, because of the space it opens up to think-feel beyond the "caged freedom" of subjective being, than by the centripetal force of an "erotic curiosity of care." What does this say about me? I'll have to think about that a little more. What it says about Huffer's 
book-event seems to be clear: her intense embrace of Madness offers a profoundly engaging and unsettling roller-coaster ride through the founding discourses of not only queer theory, but of subjectivity itself. One does not have to love Foucault to find this exciting-or, indeed, deliciously unbecoming.

renée c. hoogland teaches modern literature, cultural studies, critical theory, and gender $\mathcal{E}$ sexuality studies in the English Department at Wayne State University. She is currently working on a book entitled " A Violent Embrace: Art and Aesthetics Post-Representation." 